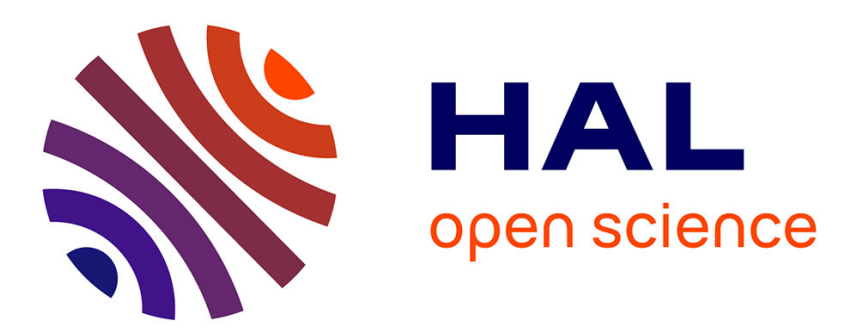

\title{
Hydrogen bond directed molecular recognition in water in a strapped-porphyrin-cyclodextrin assembly
}

\author{
Hiroaki Kitagishi, Kazuki Ohara, Daiki Shimoji, Maxime Vonesch, Jean \\ Weiss, Jennifer Wytko
}

\section{- To cite this version:}

Hiroaki Kitagishi, Kazuki Ohara, Daiki Shimoji, Maxime Vonesch, Jean Weiss, et al.. Hydrogen bond directed molecular recognition in water in a strapped-porphyrin-cyclodextrin assembly. Journal of Porphyrins and Phthalocyanines, 2019, 23 (4-5), pp.569-574. 10.1142/S1088424619500494 . hal02498700

\section{HAL Id: hal-02498700 \\ https://hal.science/hal-02498700}

Submitted on 4 Mar 2020

HAL is a multi-disciplinary open access archive for the deposit and dissemination of scientific research documents, whether they are published or not. The documents may come from teaching and research institutions in France or abroad, or from public or private research centers.
L'archive ouverte pluridisciplinaire HAL, est destinée au dépôt et à la diffusion de documents scientifiques de niveau recherche, publiés ou non, émanant des établissements d'enseignement et de recherche français ou étrangers, des laboratoires publics ou privés. 


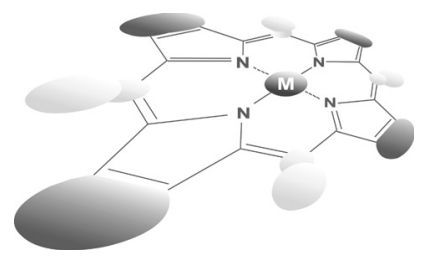

\title{
Hydrogen bond directed molecular recognition in water in a strapped-porphyrin-cyclodextrin assembly
}

\author{
Hiroaki Kitagishiª, Kazuki Oharaa ${ }^{a}$, Daiki Shimoji ${ }^{a}$, Maxime Vonesch ${ }^{b}$, \\ Jean Weiss ${ }^{\mathrm{b} \vartheta}$ and Jennifer A. Wytko ${ }^{* \mathrm{~b} \diamond}$ \\ ${ }^{a}$ Department of Molecular Chemistry and Biochemistry, Faculty of Science and Engineering, \\ Doshisha University, Kyotanabe, Kyoto 610-0321, Japan \\ b Institut de Chimie de Strasbourg, UMR 7177, CNRS, Université de Strasbourg, 4 Rue Blaise Pascal, \\ 67000 Strasbourg, France
}

This paper is part of the 2019 Women in Porphyrin Science special issue.

Received 14 March 2019

Accepted 4 April 2019

\begin{abstract}
A water soluble, phenanthroline-strapped zinc porphyrin bearing four arylsulfonate groups formed a stable host-guest complex with two per- $O$-methylated $\beta$-cyclodextrin cavities. In the host-guest assembly, the zinc porphyrin was capable of binding imidazole within the cavity between the zinc(II) ion and the phenanthroline strap in an aqueous medium. The formation of a hydrogen bond between the imidazole $\mathrm{NH}$ and the nitrogen atoms of the phenanthroline was an essential element of the binding event, as shown by comparative binding studies with a non-strapped tetrasulfonated zinc porphyrin and with $N$-methylimidazole. This hydrogen bonding in an aqueous medium was possible due to the protected hydrophobic environment created by the cyclodextrins around the phenanthroline strap. This type of binding event may provide a biomimetic approach to study water soluble hemeprotein models.
\end{abstract}

KEYWORDS: hydrogen bonding, aqueous medium, host-guest complex, $\beta$-cyclodextrin, porphyrin.

\section{INTRODUCTION}

The development of heme protein models has been a challenge for more than four decades. Prior to the emergence of X-ray diffraction, the initial concern was the identification and characterization of active sites in natural systems. Iron porphyrins or hemes were clearly identified as the main component of the active site of a large class of enzymes and proteins, but the efficient synthesis of these active sites was also a challenge at that time. One difficulty lies in differentiating both faces of the porphyrin macrocycle. The proximal face corresponds to the face that bears a ligand in close proximity to the central iron core, whereas on the distal face, the reactivity

\footnotetext{
${ }^{\diamond}$ SPP full member in good standing

*Correspondence to: H. Kitagishi, tel.: +81-774-65-7442, email: hkitagis@mail.doshisha.ac.jp; J. Wytko, tel.: +33-36885-14-24, email: jwytko@unistra.fr.
}

and accessibility of the heme iron center, is controlled by distant residues.

Utilization of nitro-aryl-aldehydes allowed the preparation of a basic building block, namely the mesotetraaminophenyl porphyrin [1] that could be further functionalized to fine tune the distal site of the heme, hence paving the way to further-refined functions of the models [2]. Surprisingly, the basic design concepts of heme protein models have evolved much less than our understanding of the complexity in controlling heme reactivity in natural systems via protein mutations or heme substitution [3], the use of small peptide-appended porphyrins [4] or the noncovalent association of synthetic hemes with monoclonal antibodies [5]. The field of synthetic heme protein models seems to have reached a conceptual steady state in which efficient mimics are too complicated for applications to be developed, and models are too simple and do not perform well enough.

A notable innovation associated simple commercial iron porphyrins with an exogenic environment consisting 


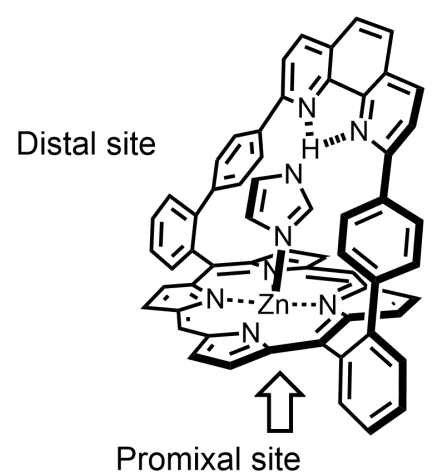

Fig. 1. A phenanthroline-strapped zinc porphyrin with an imidazole bound at the distal site, defined by the phenanthroline pocket. The proximal site is the open face of the zinc porphyrin

in a functionalized $\beta$-cyclodextrin ( $\beta$-CD) host rather than just an exogenic proximal base [6]. CDs are a widely studied class of host molecules possessing an internal hydrophobic cavity and an external hydrophilic envelope. The inclusion of iron porphyrins within cyclodextrins provides water-soluble heme models with a hydrophobic environment above the porphyrin macrocycle [7] and can be complemented by ligand coordination at the proximal site of the metal [8]. A set of significant studies has emerged from this novel approach and the results are extremely encouraging $[9,10]$. For example, a myoglobin model capable of oxygen binding in aqueous media was able to deplete endogenous carbon monoxide selectively [11]. However, to date, only commercially available porphyrins have been engaged in these studies.

Our groups have taken advantage of an accessible phenanthroline-strapped porphyrin to develop new bioinorganic models that contain a generic predefined distal binding site as summarized in Fig. 1 [12, 13]. A tremendous advantage of the phenanthroline-strapped structure is its synthetic availability on a gram scale within a few weeks. Over the last decade, the selective imidazole recognition $[14,15]$ within the phenanthroline strap was used to construct a family of supramolecular complexes that mimic the hetero-binuclear site of cytochrome $c$ oxidase $[12,16]$. Very simple derivatives of this strapped porphyrin can be sulfonated (Scheme 1) to favor their inclusion within $\beta$-CD hosts. We report herein the formation of a host-guest complex between a synthetic phenanthroline-strapped porphyrin and per$O$-methylated $\beta-\mathrm{CD}$ and we provide evidence for the selective distal binding of $\mathrm{N}-\mathrm{H}$ imidazoles induced by hydrogen bonding in aqueous media.

\section{RESULTS AND DISCUSSION}

The sulfonated strapped porphyrin was synthesized in three steps starting from the dibromo-porphyrin $\mathbf{1}$ [15], as shown in Scheme 1. The latter was reacted with phenyl boronic acid under classical biphasic Suzuki cross-coupling conditions to afford the bis(mesophenyl)-strapped porphyrin 2 in $49 \%$ yield. Compound 2 was then sulfonated in concentrated sulfuric acid to afford the tetrasulfonated derivative $\mathbf{3}$ in $65 \%$ yield as its ammonium salt. In addition to the high yield, the sulfonation reaction was extremely regioselective. The only isomer that was isolated and characterized by $1 \mathrm{D}$ and $2 \mathrm{D}^{1} \mathrm{H}$ NMR $\left({ }^{1} \mathrm{H}-{ }^{1} \mathrm{H} \mathrm{COSY}\right)$ experiments is the derivative represented in Scheme 1, with one sulfonate group on each of the four meso-phenyl rings. Treatment of $\mathbf{3}$ with excess $\mathrm{ZnO}$ in water led to the metallated porphyrin $\mathbf{3 Z n}$ in $26 \%$ yield. In an attempt to improve the yield of this last step, excess $\mathrm{Zn}(\mathrm{OAc})_{2}$ was reacted with $\mathbf{3}$ in THF/ $\mathrm{MeOH} /$ pyridine. The use of $\mathrm{Zn}(\mathrm{OAc})_{2}$, which can also act as a Lewis acid, led to the regioselective removal of two of the four sulfonate groups as well as metalation to afford $4 \mathbf{Z n}$ in $62 \%$ yield. The limited solubility of $\mathbf{4 Z n}$ in buffered aqueous media prevented further inclusion studies with $\beta$-CD.

The interaction of the sulfonated strapped porphyrin with permethylated $\beta-\mathrm{CD}$ (TMe- $\beta-\mathrm{CD})$ was investigated

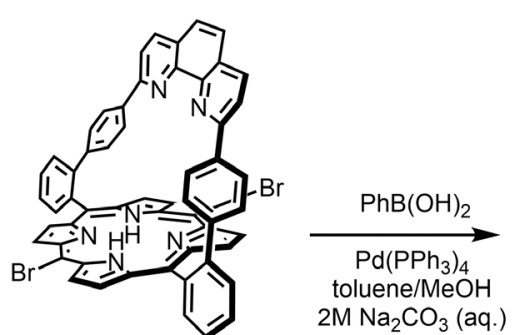

1
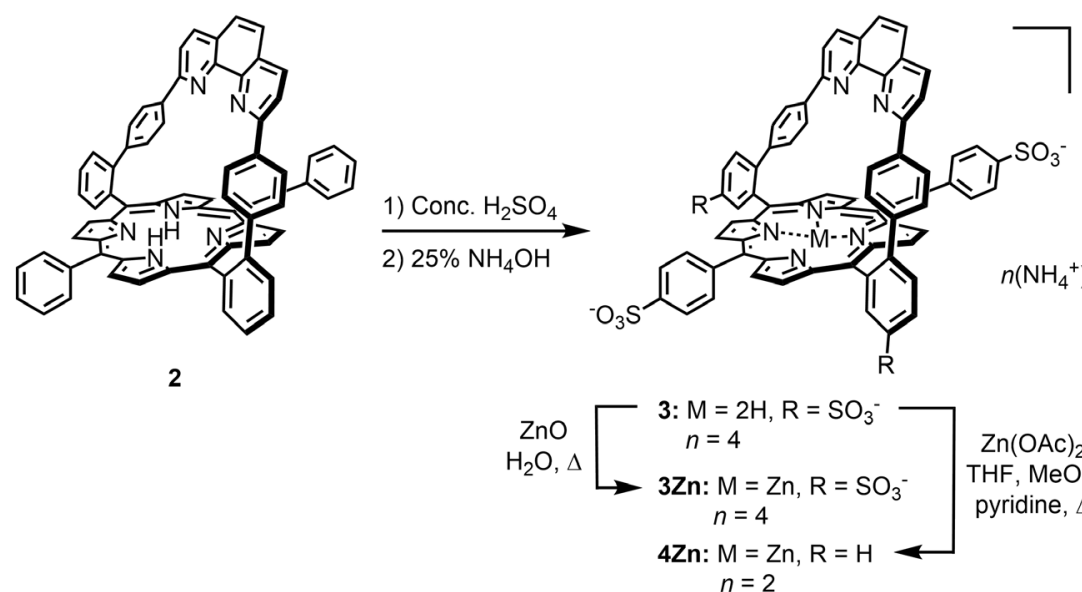

$\mathrm{Zn}(\mathrm{OAc})_{2}$ THF, MeOH pyridine, $\triangle$

Scheme 1. Synthesis of sulfonated zinc porphyrins 

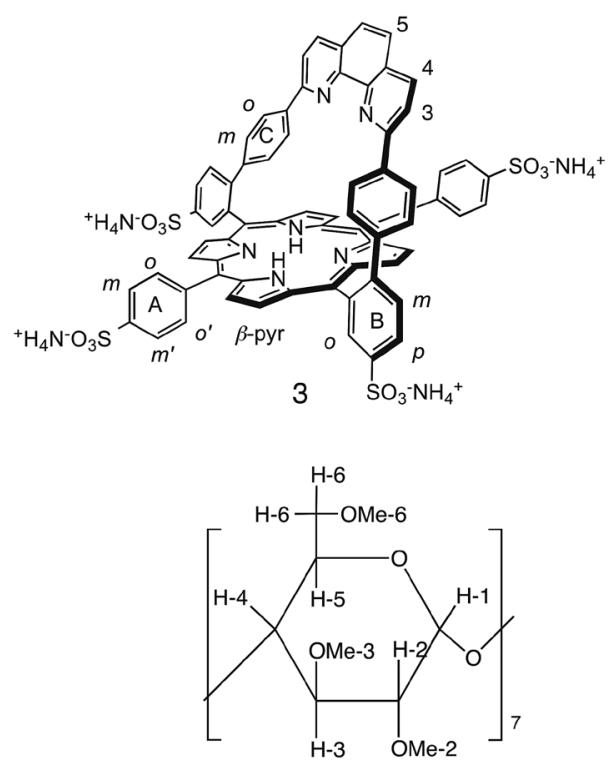

TMe- $\beta$-CD

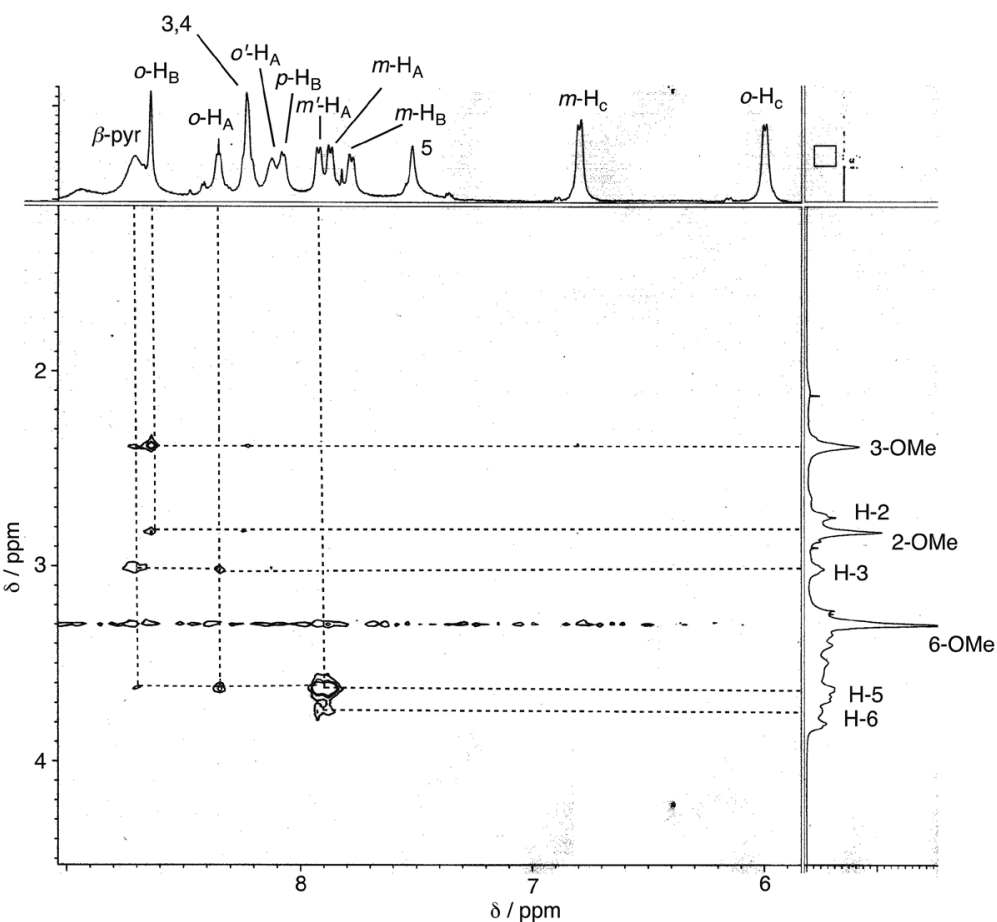

Fig. 2. ROESY NMR spectrum of the $2: 1 \mathrm{TMe}-\beta-\mathrm{CD} / \mathbf{3}$ complex $([\mathrm{TMe}-\beta-\mathrm{CD}]=2 \mathrm{mM},[\mathbf{3}]=1 \mathrm{mM})$ in $\mathrm{D}_{2} \mathrm{O}$ at $25^{\circ} \mathrm{C}$. The mixing time was $0.25 \mathrm{~s}$

by UV-vis and ${ }^{1} \mathrm{H}$ NMR spectroscopies for $\mathbf{3}$ and $\mathbf{3 Z n}$ in aqueous media. Titrations of $\mathbf{3}$ or $\mathbf{3 Z n}$ yielded a new species which ceased to evolve after the addition of two equivalents of TMe- $\beta-\mathrm{CD}$, thus confirming the stoichiometry of the supramolecular inclusion complex formed (see SI). In particular, the ROESY spectrum (Fig. 2) of a $2: 1$ mixture of $\mathrm{TMe}-\beta-\mathrm{CD} / 3$ in $\mathrm{D}_{2} \mathrm{O}$ shows the close proximity of protons $\mathrm{H}-5$ and $\mathrm{H}-6$ in the cyclodextrin to the $\mathrm{m}-\mathrm{H}_{\mathrm{A}}$ and $\mathrm{m}^{\prime}-\mathrm{H}_{\mathrm{A}}$ protons of the aromatic ring A (indicated in Fig. 2), which is parasubstituted with a sulfonate group. No correlations were seen between the $\mathrm{CD}$ protons and the para and meta protons $p-\mathrm{H}_{\mathrm{B}}$ and $m-\mathrm{H}_{\mathrm{B}}$ of aromatic ring $\mathrm{B}$. Together, these observations confirm the inclusion of phenyl rings A within $\mathrm{CD}$ cavities. Interactions between the methoxy groups at the 3 position (H-3 and 3-OMe in Fig. 2) of the cyclodextrin and the porphyrin's $\beta$-pyrrolic protons (labelled $\beta$-pyr) indicate that the secondary face of the cyclodextrin protects two opposite sides of the porphyrin, as previously observed for the inclusion of the nonstrapped tetraphenylporphyrin sulfonate (TPPS) within TMe- $\beta$-CD [17].

The stability constants (Table 1) for the successive equilibria of $\mathbf{3}$ and $\mathbf{3 Z n}$ bound in one or two TMe$\beta$-CD cavities were determined by UV-vis titrations in a $0.05 \mathrm{M}$ phosphate buffer (see SI). The binding constants of both $\mathbf{3}$ and $\mathbf{3 Z n}$ with TMe- $\beta-\mathrm{CD}$ are of the same order of magnitude. These stability constants were smaller than for porphyrin systems without a strap [17]; however, the values suggest that the intermolecular
Table 1. The binding constants $(K)$ for the formation of $1: 1$ and 2:1 complexation of TMe$\beta-\mathrm{CD}$ with $\mathbf{3}$ and $\mathbf{3 Z n}$ in $0.05 \mathrm{M}$ phosphate buffer

\begin{tabular}{lll}
\hline Compound & $\mathrm{K}_{1}\left(\mathrm{M}^{-1}\right)$ & $\mathrm{K}_{2}\left(\mathrm{M}^{-1}\right)$ \\
\hline $\mathbf{3}$ & $1.8 \times 10^{6}$ & $3.5 \times 10^{5}$ \\
$\mathbf{3 Z n}$ & $1.5 \times 10^{6}$ & $6.7 \times 10^{5}$
\end{tabular}

${ }^{a}$ The binding constants were determined from UV-vis titration experiments. The titration curves were analyzed using an equation for the $1: 1$ and 1:2 equilibria.

interactions are still strong and the inclusion occurs quantitatively, even in dilute aqueous media.

Among the peculiar properties of the phenanthrolinestrapped $\mathrm{Zn}$ porphyrin architectures is their ability to bind imidazoles very selectively in the phenanthroline strap in chlorinated solvents [14, 15] (Fig. 1). In this binding event, the relative inaccessibility of the metal is compensated by the formation of a bifurcated hydrogen bond between the imidazole $\mathrm{N}-\mathrm{H}$ and the nitrogen atoms of the phenanthroline. This phenomenon is markedly strong in chlorinated solvents. The aim of the present work is to determine if such selectivity could be observed in aqueous media, taking advantage of the protective presence of the cyclodextrins around the at $\mathrm{pH} 7$ and $25^{\circ} \mathrm{C}^{\mathrm{a}}$ 


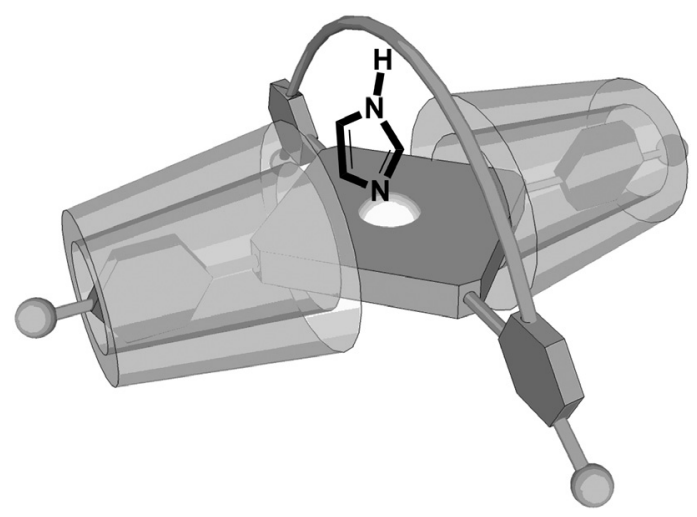

Fig. 3. Schematic representation of the $2: 1$ TMe- $\beta-C D / 3$ complex with an imidazole bound within the phenanthroline strap

Table 2. The binding constants $(K)$ for the coordination of imidazole $(\mathrm{ImH})$ and $N$-methylimidazole $(N$-MeIm) to the $\mathrm{Zn}$ porphyrin complexes without and with TMe- $\beta-\mathrm{CD}$ in $0.05 \mathrm{M}$ phosphate buffer at $\mathrm{pH} 7$ and $25^{\circ} \mathrm{C}^{\mathrm{a}}$

\begin{tabular}{lcc}
\hline Host & \multicolumn{2}{c}{$K\left(\mathrm{M}^{-1}\right)$} \\
\cline { 2 - 3 } & $\operatorname{ImH}$ & $N$-MeIm \\
\hline 3Zn & 17 & 4 \\
3Zn-(TMe- $\beta-C D)_{2}$ & 195 & $\mathrm{~b}$ \\
ZnTPPS & 75 & 77 \\
ZnTPPS-(TMe- $\beta-C D)_{2}$ & 69 & 15 \\
\hline
\end{tabular}

${ }^{a}$ The binding constants were determined based on the UV-vis titration experiments. The titration curves were analyzed using an equation for a $1: 1$ equilibrium. ${ }^{\mathrm{b}}$ Too small to be determined.

strapped porphyrin in the $\mathbf{3 Z n}(\mathrm{TMe}-\beta-\mathrm{CD})_{2}$ host-guest complex, as depicted schematically in Fig. 3. Therefore, UV-vis absorption titrations with imidazole $(\mathrm{ImH})$ were performed in aqueous media for the porphyrin-TMe$\beta$-CD supramolecular assemblies 3Zn-(TMe- $\beta-C D)_{2}$. For comparison purposes, similar titrations were performed with 3Zn, the parent ZnTPPS and ZnTPP-(TMe- $\beta-C D)_{2}$. The effects of the hydrogen bonding were evaluated by comparative titrations with $N$-methylimidazole $(N$-MeIm), which cannot form a hydrogen bond with the phenanthroline nitrogen atoms. Table 2 summarizes the binding constants determined for the formation of the ternary pentacoordinated zinc complexes.

Binding of $\operatorname{ImH}$ in the phenanthroline pocket of 3Zn was still effective in water, but much more so when protected by the cyclodextrins (see Table 2). In the presence of cyclodextrins, the binding of $\operatorname{ImH}$ to 3Zn-(TMe- $\beta-C D)_{2}$ is enhanced ten times relative to with $3 Z$ alone. When the hydrogen bonding site is unprotected, the aqueous environment perturbs the formation of a hydrogen bond between the pyrrolic proton of the $\operatorname{ImH}$ and the phenanthroline [17]. In the absence of the protective cyclodextrin environment, 3Zn displayed a significantly reduced affinity for both ImH and $N$-MeIm compared to ZnTPPS. This decrease is ascribed to the steric hindrance on one face of $\mathbf{3 Z n}$ which limits the access for ligand-metal binding. In terms of selectivity, the affinity of $\mathbf{3 Z n}$ for $\operatorname{ImH}$ is still four times higher than for $\mathrm{N}$-MeIm despite the difference in $p K_{\mathrm{a}}$ values and the higher basicity of $N$-MeIm. Although ImH and $N$-MeIm can both bind to the zinc center of $\mathbf{3 Z n}$, the greater affinity of ImH suggests that, for this substrate, a hydrogen bond still forms with the phenanthroline strap.

In comparison, the affinity of ZnTPPS-(TMe- $\beta-C D)_{2}$ for $N$-MeIm is four times lower than in the absence of TMe- $\beta$-CDs, reflecting the increased steric bulk around the zinc $d z^{2}$ orbital, which is responsible for the axial base coordination. This steric bulk explains why the equilibrium constant for the formation of a ternary complex between $3 Z \mathbf{Z n}-(\mathrm{TMe}-\beta-\mathrm{CD})_{2}$ and $N$-MeIm was too low to be measured. Based on the above, the distal site selectivity of $\mathbf{3 Z n}$-(TMe- $\beta-\mathrm{CD})_{2}$ and the enhanced binding of $\operatorname{ImH} v s . N$-Im can be attributed to the formation of a hydrogen bond between the $\mathrm{ImH}$ and the phenanthroline, in addition to metal-ligand binding. The TMe- $\beta$-CDs provide a microscopically apolar environment [18] that protects the hydrogen bonding site from the aqueous media, similar to the concept of concave phenanthroline bases established by Lüning et al. [19].

The driving force for molecular recognition processes in water is generally the formation of hydrophobic interactions between (charged) hydrosoluble guests and the hydrophobic pocket of a water-soluble host. This concept was initiated in the early 80 s by pioneering work on cyclophanes by Diederich, who aimed to mimic nature's strategy of burying a polar site within a hydrophobic pocket of a protein [20]. The concept was later extended to sophisticated cyclophanes such as calixarenes [21], resorcinarenes [22], pillarenes [23] or imprinted micelles [24], among others. The striking feature of $\mathbf{3 Z n}$-(TMe- $\beta-\mathrm{CD})_{2}$ as a receptor is that the binding enhancement can be clearly assigned to the protection of the hydrogen bonding site. If the $\mathrm{CD}$ contributed in another way to the enhanced binding, this effect would have also been detected for ZnTPPS-(TMe$\beta$-CD) $)_{2}$; however, this was not the case. Only the effects of steric encumbrance were observed, with no increased affinity for ImH compared to ZnTPPS alone.

This surprising hydrogen bond-directed recognition in an aqueous buffer for our host-guest complex suggests that discrimination of the distal $v s$. promixal site, previously observed in organic solvents, can be reproduced in aqueous media. The self-assembly of strapped porphyrins with cyclodextrins may lead to new concepts in the design of hemoprotein models and 
investigation of the reactivity of paramagnetic ferric and ferrous complexes is currently under way.

\section{EXPERIMENTAL}

\section{General methods}

${ }^{1} \mathrm{H}$ NMR spectra were recorded on a JNM-ECA500 spectrometer $(500 \mathrm{MHz})$ or a Bruker 500 spectrometer. Matrix-assisted laser desorption/ionization time-of-flight (MALDI-TOF) mass spectra were taken on a Bruker Daltonics autoflex speed spectrometer using an $\alpha$-CHCA matrix or a dianthrol matrix (for $4 \mathbf{Z n}$ only). Chemical shifts are given relative to the peak of the residual solvent: DMSO at $2.50 \mathrm{ppm}, \mathrm{CHCl}_{3}$ at $7.24 \mathrm{ppm}$. UV-vis spectra were recorded on a Shimadzu MultiSpec-1500 photodiode-array spectrometer with a thermostatic cell holder or a Cary 5000 spectrometer. The starting material, porphyrin 1, was synthesized according to a literature method [15]. Heptakis(2,3,6-tri- $O$-methyl)- $\beta$-cyclodetrin (TMe- $\beta$-CD) was purchased from Nacalai.

\section{Determination of stability constants}

Stability constants were determined according to a literature method [17]. Briefly, to aqueous phosphate buffer solution ( $\mathrm{pH} 7$ ) containing porphyrin species in a $1 \mathrm{~cm}$ cuvette were added aliquots of the stock solutions of TMe- $\beta-\mathrm{CD}$, imidazole (ImH), or $N$-methylimidazole $(N$-MeIm). After each addition, the cuvette was gently mixed, placed in a thermostatic cell holder $\left(25^{\circ} \mathrm{C}\right)$ for $5 \mathrm{~min}$, and the UV-vis absorption spectrum was measured. The titration curves obtained from the absorbance changes as a function of the additives were analyzed by a nonlinear least-squares method using a computer program (SPANA) [17]. The reproducibility of the data was checked by repeating all experiments at least three times.

\section{Synthesis}

Synthesis of 2. To a degassed solution of 1 (117 mg, $0.123 \mathrm{mmol})$ in toluene $(15 \mathrm{~mL})$ and methanol $(3 \mathrm{~mL})$ were added $\mathrm{Pd}\left(\mathrm{PPh}_{3}\right)_{4}(4 \mathrm{mg}, 0.15 \mathrm{mmol}), 1 \mathrm{~mL}$ of degassed $2 \mathrm{M} \mathrm{Na}_{2} \mathrm{CO}_{3}$ aqueous solution, and phenylboronic acid (33 mg, $0.27 \mathrm{mmol}$ ). The mixture was heated at $80^{\circ} \mathrm{C}$ for $12 \mathrm{~h}$. After cooling the mixture to room temperature, the organic layer was diluted in toluene and the solution was washed three times with a $30 \% \mathrm{NH}_{4} \mathrm{OH}$ aqueous solution. The organic phase was dried over $\mathrm{Na}_{2} \mathrm{SO}_{4}$, filtered and evaporated to dryness. The resulting solid was purified by silica gel column chromatography $\left(\mathrm{CH}_{2} \mathrm{Cl}_{2}\right)$ to afford $2(57 \mathrm{mg}, 0.060 \mathrm{mmol}, 49 \%) .{ }^{1} \mathrm{H}$ NMR $\left(\mathrm{CDCl}_{3}\right): \mathrm{ppm}$ 8.75 (br s, $8 \mathrm{H}), 8.67$ (d, $J=7.5 \mathrm{~Hz}, 2 \mathrm{H}), 8.56$ (br s, 4H), $8.00(\mathrm{~d}, J=8.0 \mathrm{~Hz}, 4 \mathrm{H}), 7.92(\mathrm{t}, J=7.5 \mathrm{~Hz}, 2 \mathrm{H}), 7.88$ $(\mathrm{d}, J=7.5 \mathrm{~Hz}, 2 \mathrm{H}), 7.82(\mathrm{t}, J=7.5 \mathrm{~Hz}, 2 \mathrm{H}), 7.72-7.70$ (m, 4H), 7.62 (br s, 2H), $7.56(\mathrm{~d}, J=8.0 \mathrm{~Hz}, 2 \mathrm{H}), 7.54$ (s, 2H), 6.82 (d, $J=8.5 \mathrm{~Hz}, 4 \mathrm{H}), 6.58(\mathrm{~d}, J=8.5 \mathrm{~Hz}$, $4 \mathrm{H}$ ), -2.42 (br s, 2H). MS: $m / z, 943.1$ (calcd. for $\mathrm{C}_{68} \mathrm{H}_{42} \mathrm{~N}_{6}$ $[\mathrm{M}+\mathrm{H}]^{+}$942.4).

Synthesis of 3. A solution of $2(57 \mathrm{mg}, 0.06 \mathrm{mmol})$ in concentrated $\mathrm{H}_{2} \mathrm{SO}_{4}(>95 \%)(30 \mathrm{~mL})$ was heated at $70{ }^{\circ} \mathrm{C}$ for $48 \mathrm{~h}$. After cooling to room temperature, the solution was further stirred for $72 \mathrm{~h}$ and then poured into the cold water ( $c a .200 \mathrm{~mL}$ ). The precipitated porphyrin was collected by centrifugation. The solid was washed several times with cold water. The solid was dissolved in $25 \% \mathrm{NH}_{4} \mathrm{OH}$ aqueous solution, and the solvent was then evaporated in vacuo to give $\mathbf{3}$ as a tetra-ammonium salt (52 mg, $0.04 \mathrm{mmol}, 65 \%$ ). ${ }^{1} \mathrm{H}$ NMR (DMSO- $d_{6}$ ): ppm $8.81(\mathrm{~d}, J=4.5 \mathrm{~Hz}, 4 \mathrm{H}) 8.78$ (br s, $2 \mathrm{H}), 8.75$ (d, $J=4.5$ $\mathrm{Hz}, 4 \mathrm{H}), 8.61(\mathrm{~d}, J=8.5 \mathrm{~Hz}, 2 \mathrm{H}), 8.28(\mathrm{~d}, J=8.0 \mathrm{~Hz}$, $2 \mathrm{H}), 8.22(\mathrm{~d}, J=7.5 \mathrm{~Hz}, 2 \mathrm{H}), 8.01(\mathrm{~d}, J=8.5 \mathrm{~Hz}, 2 \mathrm{H})$, $7.91(\mathrm{~d}, J=8.5 \mathrm{~Hz}, 2 \mathrm{H}), 7.88(\mathrm{~d}, J=7.5 \mathrm{~Hz}, 2 \mathrm{H}), 7.82$ $(\mathrm{d}, J=8.5 \mathrm{~Hz}, 2 \mathrm{H}), 7.74(\mathrm{~s}, 2 \mathrm{H}), 7.71(\mathrm{~d}, J=8.0 \mathrm{~Hz}$, $2 \mathrm{H}), 6.81(\mathrm{~d}, J=8.5 \mathrm{~Hz}, 4 \mathrm{H}), 6.72(\mathrm{~d}, J=8.5 \mathrm{~Hz}, 4 \mathrm{H})$, -2.67 (br s, 2H). MS (positive mode): $\mathrm{m} / \mathrm{z} 1264.0$ (calcd. for $\mathrm{C}_{68} \mathrm{H}_{43} \mathrm{~N}_{6} \mathrm{O}_{12} \mathrm{~S}_{4}\left[\mathrm{M}-4 \mathrm{NH}_{4}+5 \mathrm{H}\right]^{+}$1263.2). EA calcd. for $\mathrm{C}_{68} \mathrm{H}_{38} \mathrm{~N}_{6} \mathrm{O}_{12} \mathrm{~S}_{4}^{4-} \cdot 4 \mathrm{NH}_{4}^{+} \cdot 9 \mathrm{H}_{2} \mathrm{O}: \mathrm{C}, 54.68 ; \mathrm{H}, 4.86, \mathrm{~N}$, 8.38; found: C, 54.78, H, 4.49, N 8.16.

Synthesis of 3Zn. A mixture of $3(8.2 \mathrm{mg}, 6.5 \mu \mathrm{mol})$ and $\mathrm{ZnO}(17 \mathrm{mg}, 0.21 \mathrm{mmol})$ in $\mathrm{H}_{2} \mathrm{O}(25 \mathrm{~mL})$ was refluxed for 2 days. After confirming the complete metalation by fluorescence spectroscopy, the mixture was cooled to room temperature. The excess $\mathrm{ZnO}$ was filtered off and the filtrate was concentrated to $1 \mathrm{~mL}$ in vacuo. The solution was passed through a Sephadex G-25 column to afford 3Zn (2.2 mg, $1.7 \mu \mathrm{mol}, 26 \%)$. UV-vis (phosphate buffer at $\mathrm{pH} 7.0) \lambda_{\max }, \mathrm{nm}\left(\varepsilon\right.$ in $\left.\mathrm{M}^{-1} \cdot \mathrm{cm}^{-1}\right) ; 430\left(4.5 \times 10^{5}\right)$, $561\left(3.7 \times 10^{4}\right), 605\left(2.0 \times 10^{4}\right)$. MS (negative mode): $\mathrm{m} / \mathrm{z} 1324.0$ (calcd for $\mathrm{C}_{68} \mathrm{H}_{39} \mathrm{~N}_{6} \mathrm{O}_{12} \mathrm{~S} / \mathrm{Zn}\left[\mathrm{M}-4 \mathrm{NH}_{4}+\right.$ $3 \mathrm{H}]^{-}$1323.1).

Synthesis of 4Zn. A mixture of 3 (25 mg, $23 \mu \mathrm{mol})$ and zinc acetate $(80 \mathrm{mg}, 0.36 \mathrm{mmol})$ was refluxed in THF $(10 \mathrm{~mL}), \mathrm{MeOH}(5 \mathrm{~mL})$ and pyridine $(0.1 \mathrm{~mL})$ for 2 days. The solution was cooled to room temperature and solvents were removed under vacuum. The residue was taken in water and sonicated. The slurry was filtered on a fritted glass funnel and the solid was washed with water. The solid was covered with $\mathrm{MeOH}(5 \mathrm{~mL})$ and aqueous ammonia $(5 \mathrm{~mL})$. This slurry was sonicated for $5 \mathrm{~min}$. The solvents were then removed under vacuum to afford $4 \mathrm{Zn}$ as a black solid (17 mg, $14 \mu \mathrm{mol}, 62 \%)$. ${ }^{1} \mathrm{H}$ NMR (500 MHz, DMSO- $d_{6}$ ): ppm $8.74(\mathrm{~d}, J=4.5$ $\mathrm{Hz}, 2 \mathrm{H}), 8.67$ (d, $J=4.5 \mathrm{~Hz}, 2 \mathrm{H}), 8.60-8.52(\mathrm{~m}, 2 \mathrm{H})$, $8.25(\mathrm{~d}, J=8.5 \mathrm{~Hz}, 2 \mathrm{H}), 8.01-7.91(\mathrm{~m}, 4 \mathrm{H}), 7.91-7.84$ (m, 4H), $7.79(\mathrm{t}, J=7.5 \mathrm{~Hz}, 2 \mathrm{H}), 7.72(\mathrm{~s}, 2 \mathrm{H}), 7.71$ $(\mathrm{d}, J=8.5 \mathrm{~Hz}, 2 \mathrm{H}), 6.76(\mathrm{~d}, J=8.5 \mathrm{~Hz}, 4 \mathrm{H}), 6.66(\mathrm{~d}$, $J=8.5 \mathrm{~Hz}, 4 \mathrm{H})$. UV-vis $(\mathrm{MeOH}) \lambda_{\max }, \mathrm{nm}$ (rel. abs.): 286 (0.14), 312 (0.14), 407 (0.09), 430 (1), 562 (0.04), 602 (0.01). MS: $m / z 1165.26$ (calcd for $\mathrm{C}_{68} \mathrm{H}_{41} \mathrm{~N}_{6} \mathrm{O}_{6} \mathrm{~S}_{2} \mathrm{Zn}$ $\left.\left[\mathrm{M}-2 \mathrm{NH}_{4}+3 \mathrm{H}\right]^{+} 1165.18\right)$. 


\section{Acknowledgments}

This work was supported by the CNRS, the Université de Strasbourg and the French Ministry of Research and Education, MEXT/JSPS KAKENHI (Grant No. 17H02208 and 18KK0156), and the MEXT-Supported Program for the Strategic Research Foundation at Private Universities (2015-2019).

\section{Supporting information}

Additional spectral data for $\mathbf{3}, \mathbf{3 Z n}$ and $\mathrm{Zn}^{\mathrm{II}} \mathrm{TPPS} /$ TMe- $\beta-C D$, Figs S1-S9, are given in the supplementary material. This material is available free of charge via the Internet at http://www.worldscinet.com/jpp/jpp.shtml.

\section{REFERENCES}

1. Collman JP and Fu L. Acc. Chem. Res. 1999; 32: 455-453.

2. Collman JP, Herrmann, PC, Boitrel B, Zhang X, Eberspacher TA, Fu L, Wang J, Rousseau DL and Williams ER. J. Am. Chem. Soc. 1994; 116: 9783-9784.

3. Oohora K, Tang N, Morita Y and Hayashi T. J. Biol. Inorg. Chem. 2017; 22: 695-703.

4. Ricoux R, Boucher JL, Mandon D, Frapart YM, Henry Y, Mansuy D and Mahy JP. Eur. J. Biochem. 2003; 270: 47-55.

5. Mahy JP, Maréchal JP and Ricoux JD. Chem. Commun. 2015; 51: 2476-2494.

6. Mosseri S, Mialocq JC, Perly B and Hambright P. J. Phys. Chem 1991; 95: 4659-4663.

7. Kano K, Kitagishi H, Tamura S and Yamada A. J. Am. Chem. Soc. 2004; 126: 15202-15210.

8. Kano K, Kitagishi H, Kodera M and Hirota S. Angew. Chem., Int. Ed. 2005; 44: 435-438.

9. (a) Zhou H and Groves JT. Biophys. Chem. 2003; 105: 639-648; (b) Zhou H and Groves JT. J. Porphyrins Phthalocyanines 2004; 8: 125-140.

10. (a) Kano K, Kitagishi H, Dagallier C, Kodera M, Matsuo T, Hayashi T, Hisaeda $\mathrm{Y}$ and Hirota S. Inorg. Chem. 2006; 45: 4448-4460; (b) Kano K, Ochi, T, Okunaka S, Ota Y, Karasugi K, Ueda T and Kitagishi H. Chem. Asian J. 2011; 6: 2946-2955; (c) Watanabe K, Kitagishi H and Kano K. Angew. Chem., Int. Ed. 2013; 52: 6894-6897.
11. Kitagishi H, Minegishi S, Yumura A, Negi S, Taketani S, Amagase Y, Mizukawa Y, Urushidani T, Sugiura Y and Kano K. J. Am. Chem. Soc. 2016; 138: 5417-5425.

12. Lo M, Mahajan D, Wytko JA, Boudon C and Weiss J. Org. Lett. 2009; 11: 2487-2890.

13. (a) Melin F, Trivella A, Lo M, Ruzié C, Hijazi I, Oueslati N, Wytko JA, Boitrel B, Boudon C, Hellwig $\mathrm{P}$ and Weiss J. J. Inorg. Biochem. 2012; 108: 196-202; (b) Kahlfuss C, Wytko JA and Weiss J. ChemPlusChem 2017; 4: 584-594.

14. (a) Brandel J, Trabolsi A, Melin F, Elhabiri M, Weiss J and Albrecht-Gary AM. Inorg. Chem. 2007; 46: 9534.

15. Paul D, Melin F, Hirtz C, Wytko J, Ochsenbein P, Bonin M, Schenk K, Maltese P and Weiss J. Inorg. Chem. 2003; 42: 3779-3787.

16. Vorburger P, Lo M, Choua S, Bernard M, Melin F, Oueslati N, Boudon C, Elhabiri M, Wytko JA, Hellwig P and Weiss J. Inorg. Chim. Act. 2017; 468: 232-238.

17. Kano K, Nishiyabu R, Asada $\mathrm{T}$ and Kuroda $\mathrm{Y}$. J. Am. Chem. Soc. 2002; 12: 9937-9944.

18. (a) Adrian JC Jr and Wilcox CS. J. Am. Chem. Soc. 1991; 113: 678-680; (b) Fersht A. Trends Biochem. Sci. 1987; 12: 301-304.

19. Luning U, Baumstark R, Wangnick C, Muller M, Schyja W, Gerst M and Gelbert M. Pure Appl. Chem. 1993; 65: 527-532.

20. (a) Diederich F and Dick K. Tetrahedron Lett. 1982; 23: 3167-3170; (b) Diederich F and Dick K. J. Am. Chem. Soc. 1984; 106: 8024-8036.

21. For recent examples: (a) Collin S, Parrot A, Marcelis L, Brunetti E, Jabin I, Bruylants G, Bartik K and Reinaud O. Chem. - Eur. J. 2018; 24: 17964 17974; (b) Lascaux A, De Leener G, Fusaro L, Topić F, Rissanen K, Luhmer M and Jabin I. Org. Biomol. Chem. 2016; 14: 738-746; (c) Peňuelas-Haro G and Ballester P. Chem. Sci. 2019; 10: 2413-2423.

22. Haino T, Rudkevich DM, Shivanyuk A, Rissanen K and Rebek J Jr. Chem. - Eur. J. 2000; 6: 3797-3805.

23. Shu X, Xu K, Hou D and Li C. Isr. J. Chem. 2017; 58: $1230-1240$.

24. Gunasekara RW and Zhao Y. Org. Lett. 2018; 19: 4159-4162. 